\title{
Grain Quality Parameters as Influenced by Various Sources of Zinc and Iron
}

\author{
E. Ajay Kumar ${ }^{1 *}$, K.Surekha ${ }^{2}$, K. Bhanu Rekha ${ }^{3}$ and S. Harish Kumar Sharma ${ }^{4}$ \\ ${ }^{1}$ Department of Soil Science, PJTSAU Rajendranagar, Hyderabad, India \\ ${ }^{2}$ Department of Soil Science, ICAR-Indian Institute of Rice Research, Hyd-30, India \\ ${ }^{3}$ Department of Agronomy, College of Agriculture, Rajendranagar, Hyd-30, India \\ ${ }^{4}$ Department of Soil Science, College of Agriculture, Rajendranagar, Hyd-30, India
}

*Corresponding author

\section{A B S T R A C T}

K e y w o r d s
Zinc, Iron, Quality
parameters and
Finger millet

A field experiment was conducted during Kharif 2018 at College Farm, College of Agriculture, PJTSAU to evaluate the effect of various sources of zinc and iron on grain quality parameters of fingermillet. The experiment was laid out in a randomized block design with 14 treatments and replicated thrice.The results revealed that application of different Zinc and iron sources at different rates significantly influenced the grain quality parameters (protein and calcium content) of finger millet. Highest protein $(11.25 \%)$ and calcium content $(2.33 \%)$ in grain were obtained in the treatment receiving RDF + foliar application of $\mathrm{FeSO}_{4}$ @ $0.5 \%$ twice at 30 and 60 DAS which was on par with treatment receiving RDF + foliar application of Fe-humate twice at 30 and 60 DAS $(10.90 \%$ and $2.0 \%)$ and the lowest $(6.25 \%)$ and calcium content $(1.10 \%)$ were recorded with application of RDF alone. Other than protein and calcium content there was no significant differences between treatments with respect to $\mathrm{N}, \mathrm{P}, \mathrm{K}, \mathrm{Zn}, \mathrm{Fe}$, and carbohydrate content

\section{Introduction}

Ragi is commonly known as "Nutritious millet" on account of its superiority to many cereals (rice, corn and sorghum) in terms of proteins, minerals, iron, calcium and vitamins in abundance. Finger millet is considered as wholesome food for diabetic patients. Grain may also be malted and flour of the malted grain is used as cakes or porridge and a nourishing food for infants and invalids (Chaturvedi and Srivastava, 2008). Finger millet is locally known as ragi and mandua
(India). It is an important staple food in parts of eastern and central Africa and India (Singh and Rita, 2011). Malnutrition and undernourishment are the major problems of Indian population due to which millets are becoming alternate source of human food globally as well as in India. The calcium content in this crop is higher than all other cereals while, the iodine content is said to be highest among all the food grains. Moreover, antioxidant properties, and phytochemicals make it easily and slowly digestible and help to control blood glucose levels in diabetes 
patients very efficiently. Ragi has the best quality protein along with the presence of essential amino acids, vitamin A, vitamin B and phosphorus (Gopalan et al., 2004). Besides this, the importance of micronutrients such as zinc and iron in improving the quality of food or value addition also needs to be evaluated to overcome the imbalance of nutrients in the produce. With the changes in scenario of utilization of processed products and awareness among the consumers about the health benefits, finger millet has gained importance on account of its functional components, such as slowly digestible starch and resistant starch (Wadikar et al., 2007). It is reported that during malting process, calcium and phosphorus content increases, whereas iron content decreases (Sangita and Sarita, 2000). Cakmak (2008), concluded that foliar or combined soil and foliar application of zinc fertilizer under field conditions is highly effective and very practical way to maximize uptake and accumulation of zinc in whole wheat grain.

Finger millet flour fortified with zinc oxide was specifically examined for the bio accessibility of the fortified mineral, as measured by in vitro, stimulated gastrointestinal digestion procedure and storage stability (Bhumika and Kalpana, 2010). Iron is an essential plant nutrient required for electron transport in photosynthesis. However, application of iron fertilizers may overcome its deficiency in soil and increase crop yields which will subsequently increase crop productivity and income of the farmers (Vikash et al., 2015).

\section{Materials and Methods}

The experiment was carried out during Kharif 2018 at College Farm, College of Agriculture, PJTSAU. The experimental site is geographically located at $17^{\circ} 19^{\prime} \mathrm{N}$ latitude and $78^{\circ} 23^{\prime} \mathrm{E}$ longitude at an altitude of 542.6 $m$ above mean sea level on HyderabadBangalore National highway. The soil of the experimental site was sandy loam soil which is low in organic carbon $(0.42 \%)$, available nitrogen $\left(132 \mathrm{~kg} \mathrm{ha}^{-1}\right), \mathrm{P}_{2} \mathrm{O}_{5}\left(18.13 \mathrm{~kg} \mathrm{ha}^{-1}\right)$ and high in $\mathrm{K}_{2} \mathrm{O}$ (464.8 $\left.\mathrm{kg} \mathrm{ha}^{-1}\right)$. The DTPA extractable zinc $\left(0.3 \mathrm{mg} \mathrm{kg}^{-1}\right)$ and iron $(3.8 \mathrm{mg}$ $\mathrm{kg}^{-1}$ ) was lower than the critical limit. The soil was slightly non-saline in nature. The experiment was laid out in randomized block design with 14 treatments (as detailed in Table1) and replicated thrice. The gross plot size was $4.5 \mathrm{~m} \times 4.5 \mathrm{~m}\left(20.25 \mathrm{~m}^{2}\right)$. Crop (variety GPU-28) was sown by line sowing by adopting a spacing of $30 \mathrm{~cm} \times 15 \mathrm{~cm}$. As the seed was fine it was mixed with sand to ensure optimum population. The recommended dose of fertilizer was 60:40:30 $\mathrm{kg} \mathrm{N}, \mathrm{P}_{2} \mathrm{O}_{5}$ and $\mathrm{K}_{2} \mathrm{O} \mathrm{ha}^{-1}$. Entire recommended dose of phosphorous and potassium were applied as basal dose in the form of DAP and MOP. Uniform dose of nitrogen was applied through urea in 3 equal splits $\left(1 / 3^{\text {rd }}\right.$ as basal and $1 / 3^{\text {rd }}$ at vegetative phase and remaining $1 / 3^{\text {rd }}$ ) at panicle initiation stage to all the plots.

\section{Results and Discussion}

\section{Quality parameters}

\section{Nitrogen content in grain}

There was no significant difference among the treatments though highest nitrogen content in the grain was obtained in the treatment receiving $\mathrm{RDF}+$ foliar application of $\mathrm{FeSO}_{4}$ @ $0.5 \%$ twice at 30 and 60 DAS $(1.80 \%)$ and the lowest was recorded with application of RDF alone (1.0\%) (Table 2 and Figure 1).

Application of either $\mathrm{Fe}$ or $\mathrm{Zn}$ significantly increased $\mathrm{N}, \mathrm{P}, \mathrm{Fe}$ and $\mathrm{Zn}$ content in grain and straw of rice as compared to control (Patel et al., 2017). 


\section{Phosphorus content in grain}

There was no significant difference among the treatment and the highest phosphorus content $(0.48 \%)$ in grain was noticed in treatment receiving $\mathrm{RDF}+$ foliar application of $\mathrm{FeSO}_{4} @ 0.5 \%$ twice at 30 and $60 \mathrm{DAS}$ and lowest was recorded with application of RDF alone $(0.30 \%)$. Application of either $\mathrm{Fe}$ or Zn significantly increased N, P, Fe and Zn content in grain and straw of rice as compared to control (Patel et al., 2017) (Table 2 and Figure 2).

\section{Potassium content in grain}

There was no significant difference among the treatments though highest potassium content $(0.68 \%)$ in grain was recorded in treatment receiving $\mathrm{RDF}+$ foliar application of $\mathrm{FeSO}_{4} @ 0.5 \%$ twice at 30 and $60 \mathrm{DAS}$ and lowest was recorded with application of RDF alone (0.47\%) (Table 2 and Figure 3).

\section{Iron $(\mathrm{Fe})$ content in grain}

There was no significant difference among the treatments though highest iron content $(160 \mathrm{ppm})$ in grain was noticed in treatment receiving $\mathrm{RDF}+$ foliar application of $\mathrm{FeSO}_{4}$ @ $0.5 \%$ twice at 30 and $60 \mathrm{DAS}$ and lowest was recorded with application of RDF alone $(151 \mathrm{ppm})$. Foliar spray of iron $(\mathrm{Fe})$ and zinc (Zn) fertilizers are known to be an effective way to improve $\mathrm{Fe}$ and $\mathrm{Zn}$ concentrations in rice grain (Yuan et al., 2012). It can be concluded that the foliar application of zinc and iron fertilizers have positive effect on growth, yield components and grain yield by wheat when plants are not able to absorb the iron and zinc from soil due to high soil $\mathrm{pH}$.

Table.1 Treatment details

\begin{tabular}{|c|c|c|}
\hline S.No. & Treatments & Treatments \\
\hline 1 & $\mathrm{~T}_{1}$ & $\mathrm{RDF}\left(60-40-30 \mathrm{Kg} \mathrm{N}-\mathrm{P}_{2} \mathrm{O}_{5}-\mathrm{K}_{2} \mathrm{O} \mathrm{ha}^{-1}\right)$ \\
\hline 2 & $\mathrm{~T}_{2}$ & Vermicompost@5.0 tha ${ }^{-1}+\mathrm{RDF}$ \\
\hline 3 & $\mathrm{~T}_{3}$ & $\mathrm{RDF}+\mathrm{ZnSO}_{4} @ 50 \mathrm{~kg} \mathrm{ha}^{-1}$ soil application \\
\hline 4 & $\mathrm{~T}_{4}$ & $\mathrm{RDF}+\mathrm{ZnSO}_{4} @ 0.2 \%$ foliar spray twice at 30 and 60 days after sowing \\
\hline 5 & $\mathrm{~T}_{5}$ & RDF+Zn-EDTA soil application@ @ $10 \mathrm{~kg} \mathrm{ha}^{-1}$ \\
\hline 6 & $\mathrm{~T}_{6}$ & $\begin{array}{l}\text { RDF + Zn-EDTA foliar spray @ } 0.1 \% \text { twice at } 30 \text { and } 60 \text { days after } \\
\text { sowing }\end{array}$ \\
\hline 7 & $\mathrm{~T}_{7}$ & RDF + Zn Humate soil application @ $42 \mathrm{~kg} \mathrm{ha}^{-1}$ \\
\hline 8 & $\mathrm{~T}_{8}$ & $\begin{array}{l}\text { RDF + Zn Humate foliar spray @ } 0.25 \% \text { twice at } 30 \text { and } 60 \text { days after } \\
\text { sowing }\end{array}$ \\
\hline 9 & $\mathrm{~T}_{9}$ & $\mathrm{RDF}+\mathrm{FeSO}_{4} @ 50 \mathrm{~kg} \mathrm{ha}^{-1}$ soil application \\
\hline 10 & $\mathrm{~T}_{10}$ & $\mathrm{RDF}+\mathrm{FeSO}_{4} @ 0.5 \%$ foliar spray twice at 30 and 60 days after sowing \\
\hline 11 & $\mathrm{~T}_{11}$ & RDF + Fe-EDTA soil application @ $10 \mathrm{~kg} \mathrm{ha}^{-1}$ \\
\hline 12 & $\mathrm{~T}_{12}$ & $\begin{array}{l}\text { RDF + Fe-EDTA foliar spray @ } 0.1 \% \text { twice at } 30 \text { and } 60 \text { days after } \\
\text { sowing }\end{array}$ \\
\hline 13 & $\mathrm{~T}_{13}$ & RDF + Fe Humate soil application @ $42 \mathrm{~kg} \mathrm{ha}^{-1}$ \\
\hline 14 & $\mathrm{~T}_{14}$ & $\begin{array}{l}\text { RDF + Fe Humate foliar spray @ } 0.25 \% \text { twice at } 30 \text { and } 60 \text { days after } \\
\text { sowing }\end{array}$ \\
\hline
\end{tabular}


Table.2 Effect of zinc and iron nutrition on grain quality parameters of finger millet

\begin{tabular}{|c|c|c|c|c|c|c|c|c|}
\hline Treatments & $\begin{array}{c}\text { N content } \\
(\%)\end{array}$ & $\begin{array}{l}\text { P content } \\
(\%)\end{array}$ & $\begin{array}{c}\text { K content } \\
(\%)\end{array}$ & $\begin{array}{c}\text { Protein } \\
\text { content } \\
(\%)\end{array}$ & $\begin{array}{l}\text { Zinc content } \\
\quad(\text { ppm })\end{array}$ & $\begin{array}{c}\text { Iron } \\
\text { content } \\
(\text { ppm) }\end{array}$ & $\begin{array}{c}\text { Calcium } \\
\text { content } \\
(\%)\end{array}$ & $\begin{array}{c}\text { Carbohydrate } \\
(\%)\end{array}$ \\
\hline $\mathbf{T}_{1}$ & 1.00 & 0.30 & 0.47 & 6.25 & 14 & 151 & 1.10 & 60 \\
\hline $\mathbf{T}_{2}$ & 1.0 & 0.32 & 0.50 & 6.25 & 14 & 152 & 1.10 & 61 \\
\hline $\mathbf{T}_{3}$ & 1.02 & 0.34 & 0.50 & 6.38 & 14 & 153 & 1.20 & 62 \\
\hline $\mathbf{T}_{4}$ & 1.20 & 0.40 & 0.59 & 7.50 & 19 & 157 & 1.60 & 65 \\
\hline $\mathbf{T}_{5}$ & 1.09 & 0.39 & 0.50 & 6.67 & 15 & 155 & 1.40 & 64 \\
\hline $\mathbf{T}_{6}$ & 1.60 & 0.45 & 0.62 & 10.0 & 17 & 158 & 1.78 & 67 \\
\hline $\mathbf{T}_{7}$ & 1.07 & 0.38 & 0.53 & 6.83 & 16 & 155 & 1.44 & 64 \\
\hline $\mathbf{T}_{8}$ & 1.73 & 0.45 & 0.64 & 10.81 & 17 & 158 & 1.80 & 67 \\
\hline $\mathbf{T}_{9}$ & 1.18 & 0.40 & 0.59 & 7.38 & 16 & 157 & 1.60 & 65 \\
\hline $\mathbf{T}_{10}$ & 1.80 & 0.48 & 0.68 & 11.25 & 18 & 160 & 2.33 & 70 \\
\hline$T_{11}$ & 1.03 & 0.37 & 0.54 & 6.44 & 15 & 153 & 1.20 & 63 \\
\hline $\mathbf{T}_{12}$ & 1.23 & 0.43 & 0.60 & 7.71 & 17 & 157 & 1.70 & 66 \\
\hline $\mathbf{T}_{13}$ & 1.17 & 0.38 & 0.55 & 7.29 & 16 & 156 & 1.57 & 64 \\
\hline $\mathbf{T}_{14}$ & 1.74 & 0.47 & 0.66 & 10.90 & 17 & 158 & 2.00 & 68 \\
\hline S. E m. \pm & 0.21 & 0.06 & 0.06 & 1.2 & 1 & 3 & 0.14 & 2 \\
\hline C.D. (0.05) & NS & NS & NS & 3.5 & NS & NS & 0.43 & NS \\
\hline
\end{tabular}


Fig.1 Effect of Zinc and Iron nutrition on $\mathrm{N}$ content (\%) in grain of finger millet

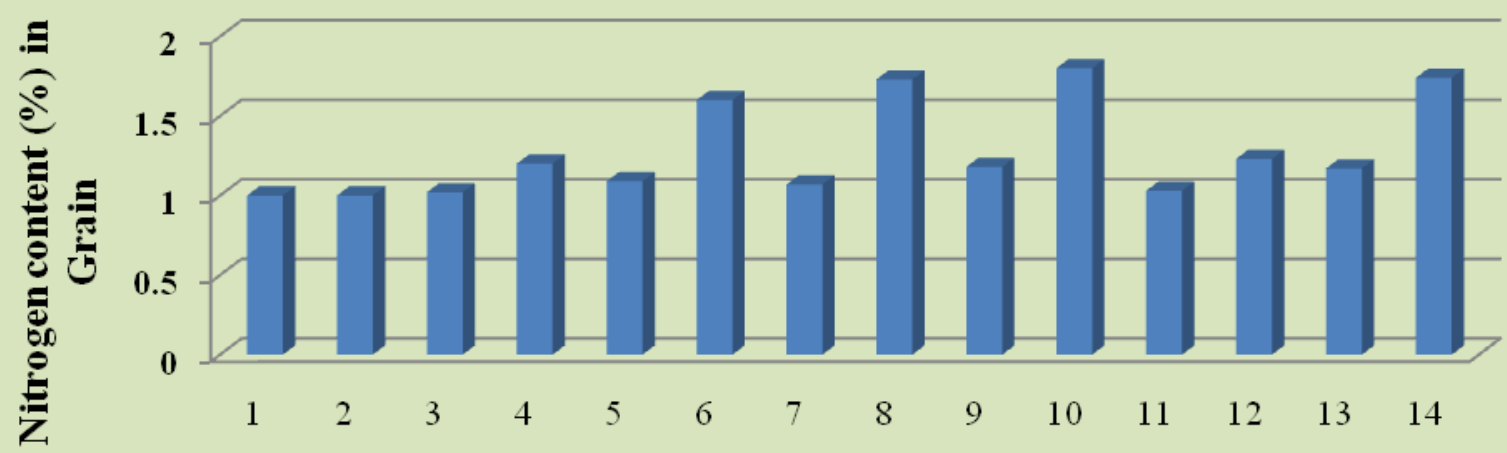

Treatments

Fig.2 Effect of Zinc and Iron nutrition on P content (\%) in grain of finger millet

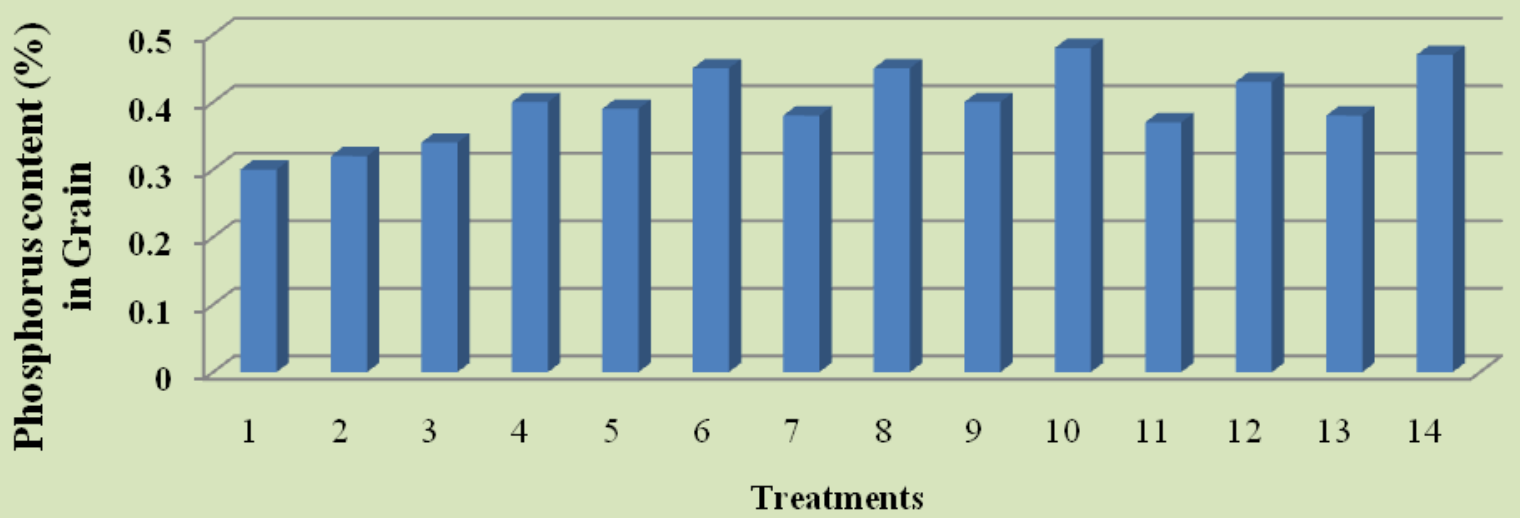

Fig.3 Effect of Zinc and Iron nutrition on K content (\%) in grain of finger millet

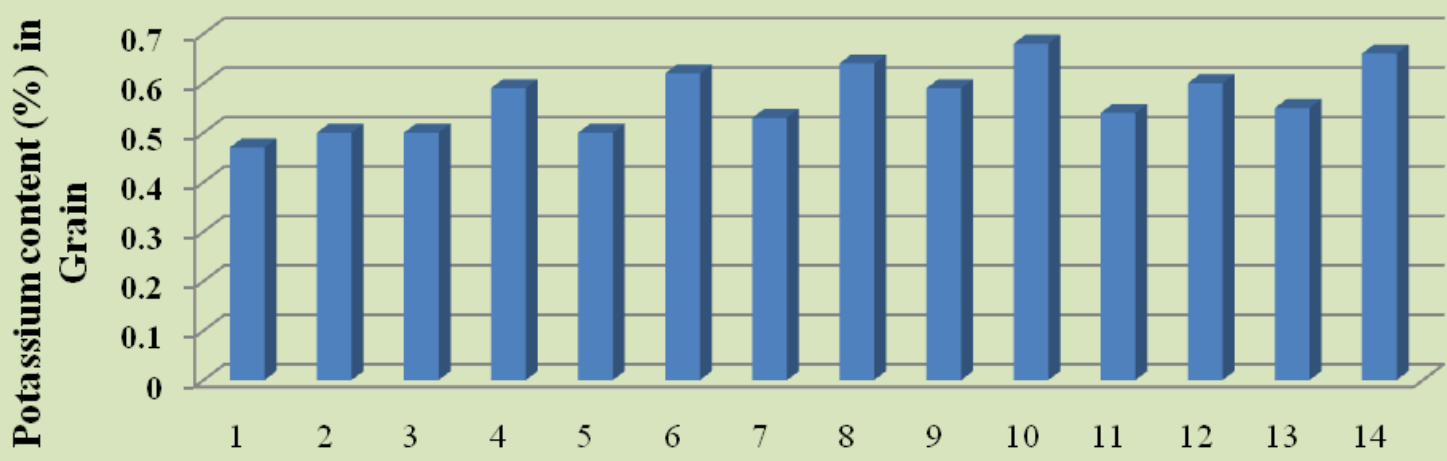

Treatments 
Fig.4 Effect of zinc and iron nutrition on protein content (\%) in grain of finger millet.

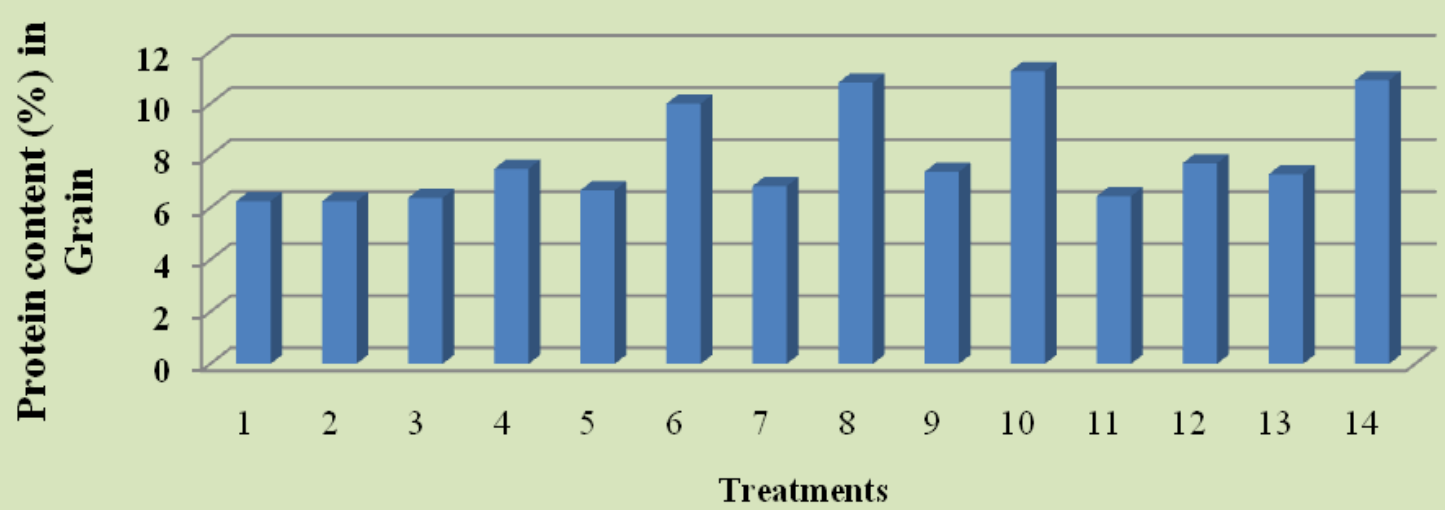

Fig.5 Effect of zinc and iron nutrition on Ca content (\%) in grain of finger mille

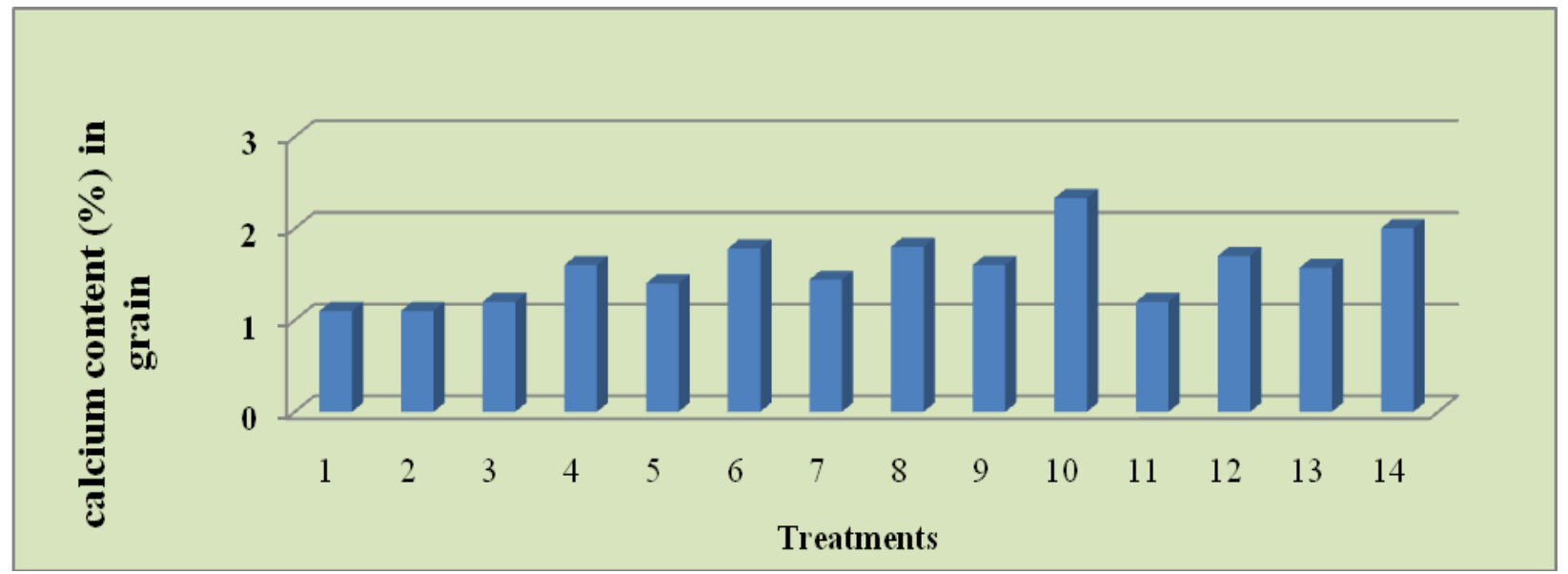

Fig.6 Effect of zinc and iron nutrition on carbohydrate (\%) in grain of finger millet
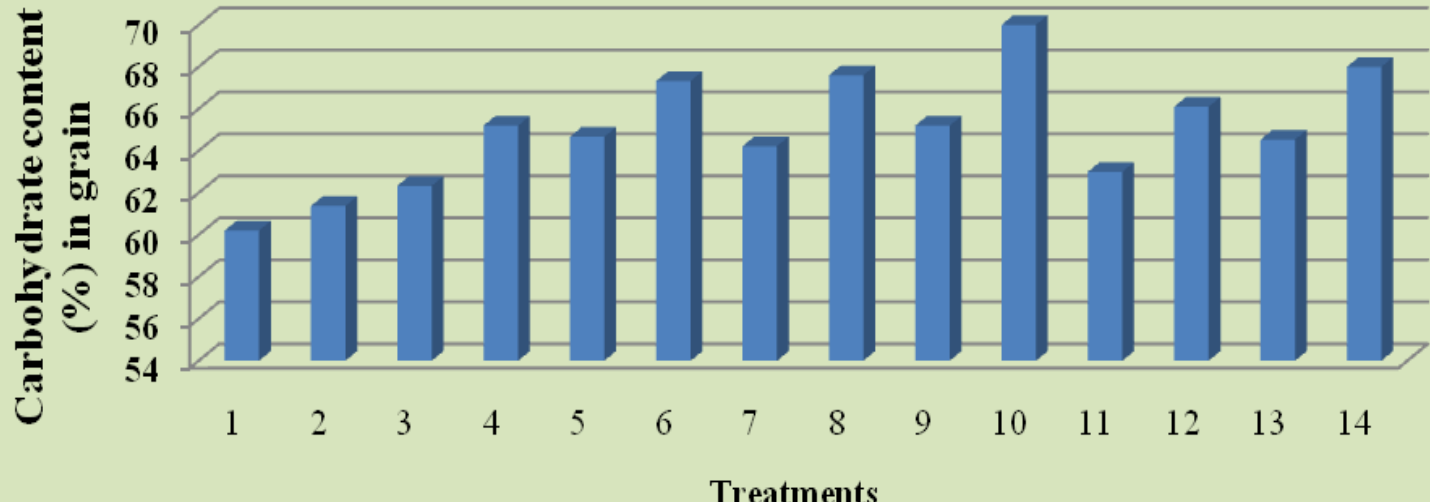

Treatments 
Fig.7 Effect of zinc and iron nutrition on Fe Content (ppm) in grain of finger millet

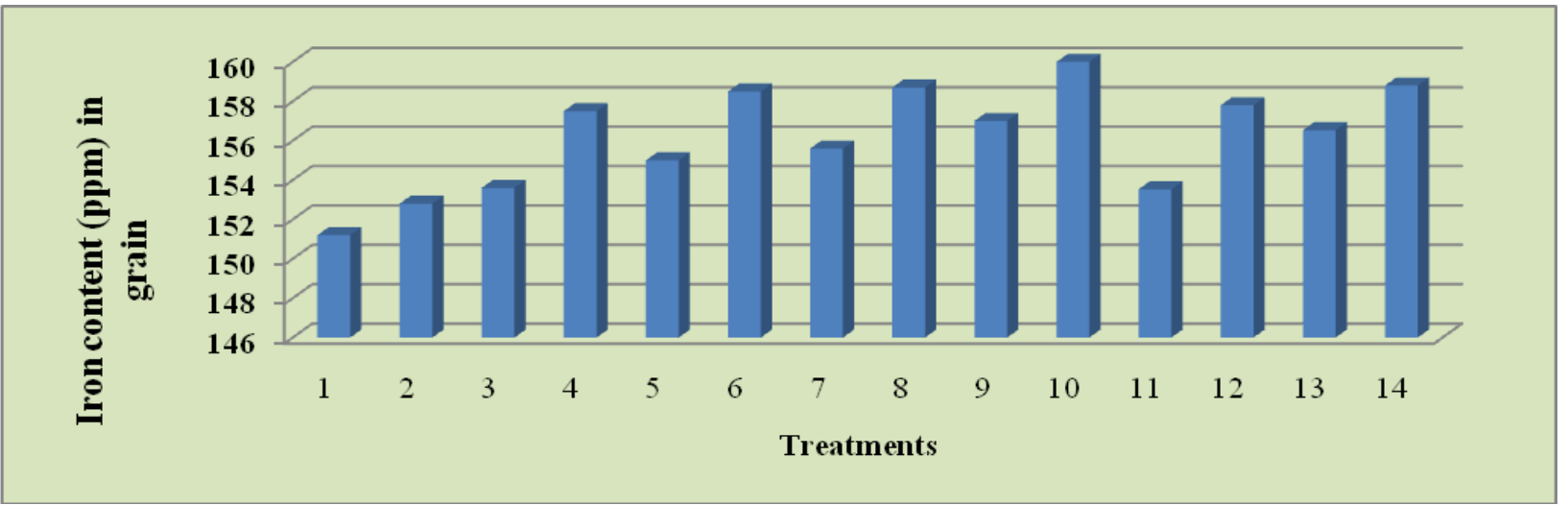

Fig.8 Effect of zinc and iron nutrition on Zn Content (ppm) in grain of finger millet

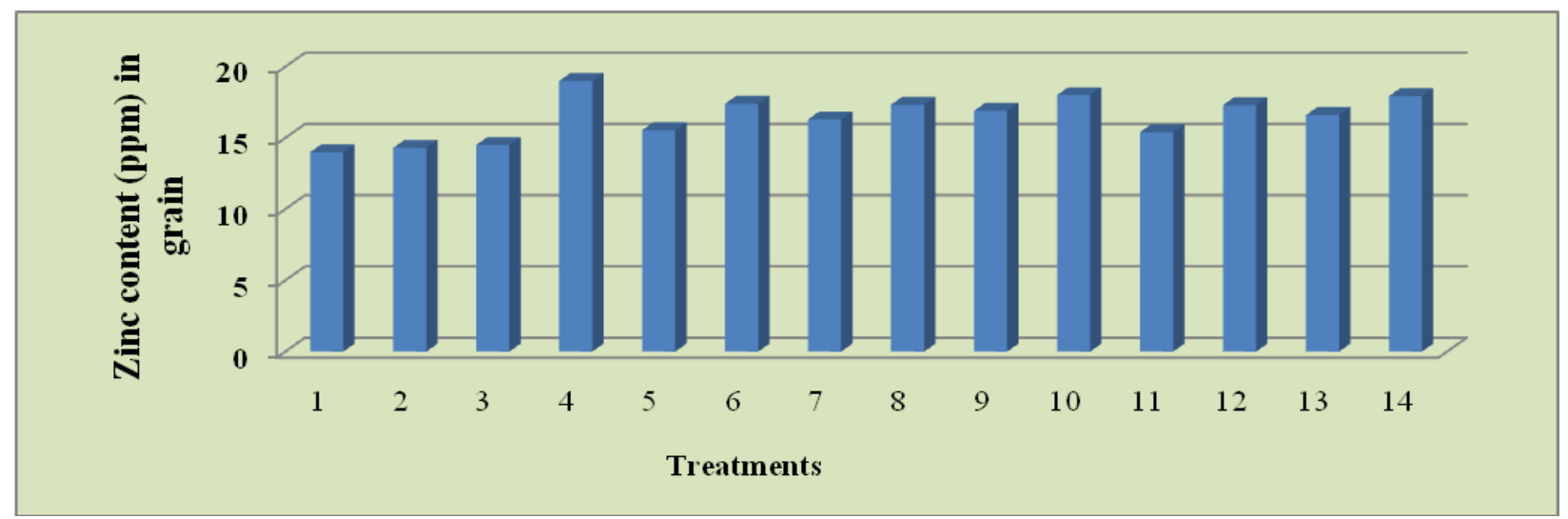

As a result, foliar application of zinc and iron develops plant growth, grain yield and enhances its quality. Under drought stress, foliar application of zinc and iron improved yield of wheat, grain filling stage being more responsive. (sultana et al., 2018). Application of either Fe or Zn significantly increased $\mathrm{N}, \mathrm{P}, \mathrm{Fe}$ and $\mathrm{Zn}$ content in grain and straw of rice as compared to control (Patel et al., 2017). (Table 2 and Figure 7).

\section{Zinc $(\mathbf{Z n})$ content in grain}

There was no significant difference among the treatments. The zinc content in grain ranged between $14 \mathrm{ppm}$ to $18 \mathrm{ppm}$ in the treatments applied with RDF alone highest zinc content and $\mathrm{RDF}+$ foliar application of $\mathrm{ZnSO}_{4} @ 0.5 \%$ twice at 30 and 60 DAS. Ramegowda et al., (2013) concluded that external application of $\mathrm{Zn}$ resulted in improved $\mathrm{Zn}$ concentration in different plant parts; in particular there was a significant increase in seed $\mathrm{Zn}$ concentration in all genotypes in finger millet. Application of either Fe or Zn significantly increased $\mathrm{N}, \mathrm{P}, \mathrm{Fe}$ and $\mathrm{Zn}$ content in grain and straw of rice as compared to control (Patel et al., 2017) (Table 2 and Figure 8).

\section{Calcium content in grain}

The calcium content in grain varied significantly among different treatments. The highest calcium content $(2.33 \%)$ in grain was noticed in treatment receiving $\mathrm{RDF}+$ foliar application of $\mathrm{FeSO}_{4} @$ $0.5 \%$ twice at 30 and 60 DAS which was on par with treatment receiving RDF + foliar application of Fe-humate $(2.0 \%)$ twice at 30 and 60 DAS and lowest was recorded with application of RDF alone ( $1.10 \%$ ) (Table 2 and Figure 5).

\section{Carbohydrate content in grain}

There was no significant difference among the treatments. The carbohydrate content ranged from 60 to $70 \%$ in plots appled with RDF+ foliar 
application of $\mathrm{FeSO}_{4} @ 0.5 \%$ twice at 30 and 60 DAS and RDF alone (Table 2 and Figure 6).

\section{Protein content in grain}

There was significant difference among the treatments and the highest protein content (11.25 $\%)$ in grain was noticed in treatment receiving $\mathrm{RDF}+$ foliar application of $\mathrm{FeSO}_{4} @ 0.5 \%$ twice at 30 and 60 DAS which was on par with treatment receiving RDF + foliar application of Fe-humate and lowest was recorded with application of RDF alone $(6.25 \%)$. Foliar application of $\mathrm{Zn}$ and $\mathrm{Fe}$ increased grain yield and protein content in wheat (Seilsepour, 2007) (Table 2 and Figure 4).

\section{References}

Cakmak, I. 2008. Enrichment of cereal grains with Zinc Agronomic or genetic bio fortification. Plant and Soil. 302(1-2): 117.

Chaturvedi, R and Srivastava, S. 2008. Genotype variations in physical, nutritional and sensory quality of popped grains of amber and dark genotype of finger millet. Journal of Food Science Technology. 45(5): 443-446.

Gopalan, C., Ramasastri, B.V and Balasubramanian SC. 2004.Nutritive value of Indian Foods. National Institute of Nutrition (NIN). Indian Council of Medical Research, Hyderabad.59-67.

Bhumika, T and Kalpana, P. 2010. Finger millet flour as a vehicle for fortification with Zinc. Journal of Trace Elements in Medicine and Biology. 24(1): 46-51.

Sangita, K and Sarita, S. 2000. Nutritive value of malted flours of finger millet genotypes and their use in the preparation of burfi.
Journal of Food Science Technology. 37(4): 419-122.

Singh, P and Rita, S.R. (2012).Finger millet for food and nutritional security. African Journal of Food Science. 6(4): 77-84.

Wadikar, D.D., Premvalli, R.S., Satyanarayan Swamy, Y.S and Bawa, A.S. 2007. Lipid profile in finger millet. Journal of Food Science Technology. 44(1): 79-81.

Vikash, K., Dinesh, K., Singh, Y.V and Rishi, R. 2015. Effect of Iron fertilization on drymatter production, yield and economics of aerobic rice (Oryza sativa L.). Indian Journal of Agronomy. 60(4): 547-553.

Ramegowda, Y., Ramegowda, R., Geetha, G., Kumar, H.G.J., Udayakumar and Shankar, A.G. 2016. Effect of zinc application on its uptake, distribution and concentration of $\mathrm{Fe}$ and $\mathrm{cu}$ in fingermillet. (Eleusine coracana (L.) Gaertn). Journal of Plant Nutrition. 39(4): 569-580.

Sultana, S., Naser, H.M., Quddus, M.A., Shil, N.C and Hossain, M.A. 2018. Effect of foliar application of iron and zinc on nutrient uptake and grain yield of wheat under different irrigation regimes. Bangladesh Journal of Agricultural Research. 43(3): 395-406.

Gohil, N.B., Patel, D.P., Patel, B.A and Pathan, O.I. 2017.Effect of soil application of $\mathrm{Fe}$ and $\mathrm{Zn}$ on nutrient content and uptake by two rice varieties. International Journal of Chemical Studies. 5(2): 396-400.

Seilsepour, M. 2007. The study of $\mathrm{Fe}$ and $\mathrm{Zn}$ effects on quantitative and qualitative parameters of winter wheat and determination of critical levels of these elements in Varamin plain soils. Pajouhesh and Sazandegi. 76: 123-133.

\section{How to cite this article:}

Ajay Kumar, E., K. Surekha, K. Bhanu Rekha and Harish Kumar Sharma, S. 2020. Grain Quality Parameters as Influenced by Various Sources of Zinc and Iron. Int.J.Curr.Microbiol.App.Sci. 9(04): 567-574. doi: https://doi.org/10.20546/ijcmas.2020.904.069 